\title{
Community Empowerment in Development Creative Economy through "Pahari" Rattan Crafts in Sabaru Kelurahan Sebangau Kota Palangka Raya
}

\author{
Dedy Ilham Perdana ${ }^{1}$, Novia Lestary ${ }^{2}$ \\ ${ }^{1,2}$ Universitas Palangka Raya, Indonesia \\ dedyilhamp@fisip.upr.ac.id
}

\begin{abstract}
Rattan woven handicrafts are creative economic enterprises that take advantage of local potential and also hone abilities and skills. Rattan is processed into handicraft items that have high selling value. The processing of handicrafts made from rattan is very attractive to the public with unique and distinctive motifs from Central Kalimantan. Empowerment of the community's economy through woven rattan handicrafts has good prospects for the future so that it can make the lives of people who are members of the pahari rattan craftsmen group prosperous. This research is a type of qualitative research. The data in this study were obtained by observation, interviews, and documentation. The main instrument in this study is the researcher himself with the help of observation guidelines, documentation guidelines, interview guides, and using other aids in the form of piles or cellphones, and writing instruments. The validity of the data was obtained by extension technique with participation, observation persistence and triangulation. Data analysis techniques are carried out by reducing data, presenting data, and drawing conclusions or verification. The results of this study indicate that (1) the process of making rattan woven bags, the process of designing, and preparing tools and materials. Production process: dye process, weaving process, assembly process and finishing process. (2) the motifs applied to the rattan woven bag craft in the Pahari Rattan Craftsmen Group are many motifs such as the lamiang motif on the ribbon tie, the dare bawak balanti motif, the dare sawang motif, the dare tie motif, the dare palapas tingang motif, the uhat djadjangkit motif, dare kilat mayambar, dare kambang malati motive, shoot dare rabung dare motif, dare anchor motif, daring rod garing dare motif, katimpun dare kambang motif, kumpang dare kumpang, dare boat motif, dare deer motif, and lamiang dare motif. (3) The types of bags produced by the Pahari Rattan Craftsmen Group are bags with various types of motifs typical of Central Kalimantan.
\end{abstract}

Keywords

empowerment; rattan craftsmen; pahari group

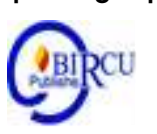

\section{Introduction}

Community empowerment is very important in responding to the challenges of very high economic growth and increasing global competition, and an absolutely mandatory thing for every element of society to do without exception. For this reason, the wider community is expected to be able to keep up with the times with community empowerment which aims to produce independent individuals in society, create an environment that has a good work ethic so as to create healthy and mutually beneficial working conditions, create a society with awareness high potential for themselves and the surrounding environment well, train and enable people to plan and be responsible for their actions in meeting their 
needs, increase the ability to think and negotiate or find solutions to problems that may be encountered in their environment, reduce the number of societies by one way to increase the potential and basic capabilities of the community.

Today's development has included empowerment as one that is prioritized in building a nation. This situation is interpreted as the existence of power or autonomy given by the government to the community in order to be able and independent in determining goodness for themselves, or in other words that there is openness from the government to accommodate various kinds of initiatives from groups that are considered to experience powerlessness or vulnerability (Adiwijaya et al, 2018). According to Mawardi et al (2019) Community empowerment as an application of government programs requires full enthusiasm from the community itself so that they will make every effort to improve the quality of their human resources in a total and continuous manner. Many efforts have indeed been carried out by the government, one of which is by providing assistance which is directly channeled to remote villages to support village development and the development of local potentials that are undoubtedly empowered.

Community empowerment is currently mostly around suburban communities. This is because the average mindset of suburban communities tends to be more backward in urban groups. The meaning of empowerment of rural communities is the process of developing the mindset and competence of rural communities so that they can match the urban community or even exceed them. Each region needs to be given the opportunity to develop their own interests and ideals. Even if there is a national interest in an area, for example as a mainstay of tourism development, the region must be given the opportunity to plan its own development goals and targets, or, it can aspire to become one of the strong economic forces through industrialization. However, the planning of such a particular ideal should be linked, among other things, to its historical setting, geographical location and development potential in relation to the supporting factors it has.

Community empowerment in the people's economy needs to be our common concern, especially in these times, where people are increasingly required to play an active role and work harder to meet the needs of their daily lives. Both men and women are required to be able to look for opportunities and opportunities so that they can work and be creative, as well as to meet needs. This is in accordance with the role of UKM as one of the creative economy development through the "Pahari Rattan Craftsmen Group". It is proven that rattan weaving has a promising market opportunity, besides the high artistic value, the benefits of rattan weaving are also environmentally friendly, favored by various groups who care about natural products of rattan weaving in Sabaru Village, Sabangau District. One of the efforts to reduce inequality can be done through community empowerment in Sabaru Village, Sebangau District.

In Kelurahan Sabaru, Sebangau Subdistrict, there is a place for the "Pahari Rattan Craftsmen Group", where local economic activity occurs. Small and Medium Enterprises (UKM), the existence of the "Pahari Rattan Craftsmen Group" is able to develop its business center with natural resources, human resources, knowledge and capital creativity.

Creativity is an important role in the development of Small and Medium Enterprises carried out by the "Pahari Rattan Craftsmen Group". Because the raw material of this business is natural resources, namely rattan, so in developing this business one must have the skills and abilities to be able to create unique handicraft items and attract buyers. The handicrafts produced by the "Pahari Rattan Craftsmen Group" have long been recognized by the wider community, such as in Palangka Raya City and its surrounding areas. Apart from that, the "Pahari Rattan Craftsmen Group" also frequently participates in cultural exhibitions, such as Isen Mulang which is held in Palangka Raya City. It can be said that 
the "Pahari Rattan Craftsmen Group" is a Small and Medium Enterprise that really helps the economy and increases income. In the handicraft place "Pahari Rattan Handicraft Group" is still doing a simple way of weaving rattan, the Pahari Group still uses simple tools for weaving, but is finished weaving and the rattan is ready to become an item that can be shaped and patterned according to customer orders, the Pahari group can use a machine sewing to make work easier and the goods produced are also more attractive. In this process, rattan mats change hands according to the craftsmanship of the craftsman. This rattan matting can last up to more than 10 years as long as it is not exposed to water in processing it not using varnish. Examples of the handicrafts of the pahari group include a purse, a tissue holder with a selling value of between Rp. 25,000 and Rp. 500,000 per piece.

This rattan weaving business was started by Ramintje and named the Pahari craftsman group, Ramintje started this rattan weaving business in the 1960s until now, Ramintje started to know rattan weaving since the age of 5 years and Ramintje's knowledge of rattan weaving has been passed down from generation to generation from his ancestors, Ramintje's mother herself taught Ramintje to weave rattan, since she was 7 years old Ramintje has been able to make crispy sticks from woven rattan. In the workshop "Pahari Rattan Craftsmen Group", there were as many as five (5) students who attended training and produced rattan woven handicrafts. Every day, they do rattan weaving activities at first, from not being able to weave so that thanks to being trained and doing the job seriously, after some time following training at the "Pahari Craftsmen Group" they are adept at processing handicrafts, although not as proficient as Ramintje in weaving. And processing rattan into goods that have a high selling value, but they can now do work without Ramintje's guidance and they can also produce wicker goods that can be traded. Ramintje's goal is to recruit students so that they are empowered and understand that in Central Kalimantan there are natural resources that should be developed and produced. In the place of "Pahari Rattan Craftsmen Group" is also rarely empty of visitors, they always get orders from inside and outside the region, so their efforts are not in vain to join the "Pahari Rattan Craftsmen Group". In reality, the business of the "Pahari Rattan Craftsmen Group" managed by Ramintje can be said to be successful in empowering students. So far, they produce goods with high selling value, even though the raw material is made of rattan but can be used and become handicraft items that are in great demand by consumers.

From the description above, the writer is interested in discussing this problem because it makes the village community empowered by the rattan weaving craft that Ramintje does for his students besides training in his own area. Ramintje also goes to various regions to provide training in weaving the goal so that our natural resources are not vacuumed and can be utilized and developed into a product that promises results to be managed and helps the community's economy, because every piece of rattan can generate money and become a source of pride for we, the people of Central Kalimantan already have a lot of natural potential that can be used and generate money, researchers are very interested in raising this title because Ramintje has been successful in this business and developed the natural potential that is owned in Central Kalimantan, making various kinds of rattan woven handicrafts with various motifs and Ramintje handicrafts have been known to various regions, and in the end the researchers raised the title of research because researchers were very interested in the success of Ramintje's hard work by exploiting the natural potential in Central Kalimantan, therefore researchers were interested took up this research.

Etymologically, empowerment comes from the basic word "power" which means strength or ability. Starting from this definition, empowerment can be interpreted as a 
process to obtain power, strength and ability, and or the process of giving power, strength or ability from parties who have power to parties who are less or less empowered. Empowerment means to make something empowered or have power or have strength. Empowerment in Indonesian is a translation of empowerment in English. Empowerment as a translation of empowerment according to Webster in the Oxford English Dictionary contains two meanings: a. To give ability or enable to, which is translated as giving skills / abilities or enabling. b. To give power of authority to, which means to give strength / power. Empowerment is a process to make people more empowered or more capable to solve their own problems, by providing trust and authority so as to foster a sense of responsibility.

Empowerment can be started by encouraging people to want to play a more active role in their work, to involve them in making decisions or responsibilities to complete the work. According to Parsons (1994), empowerment emphasizes that people acquire sufficient skills, knowledge and power to influence their lives and the lives of others who concern them. Pranarka and Vidhyandika (1996) explain that the empowerment process contains two tendencies. First, the empowerment process which emphasizes the process of giving or transferring part of the strength, power or ability to the community so that individuals are more empowered. According to Sulistiyani (2004), it is explained that the goal to be achieved from community empowerment is to form individuals and communities to become independent. This independence includes the independence of thinking, acting and controlling what they do. Community independence is a condition experienced by the community which is characterized by the ability to think, decide and do something that is deemed appropriate in order to achieve solutions to problems faced by using their own power / abilities.

Competence is closely related to a person's ability to do his job. Competence is the accumulation of an individual's ability to carry out his work in which there are elements of knowledge, attitudes, skills, and other personal elements. Competence is very complex. Therefore, to measure a person's competence, indicators that cover all these elements are needed. According to Spencer and Spencer (1993), in individuals there are five types of competencies, namely:

1. Motive, competencies related to the consistent thinking of individuals and encouraging them to take action (behave).

2. Inborn traits, competencies related to independent character or character that make individuals behave in certain ways. These innate traits include: self-confidence, endurance, and others.

3. Self concept, competencies related to the attitudes and values of the individual.

4. Knowledge, competencies related to information or knowledge possessed by individuals in certain fields of work.

5. Skills, competencies related to the individual's physical or mental work 


\section{Research Methods}

In the research approach used is qualitative research. The approach used in this study is a qualitative approach. Qualitative research method is a research that aims to understand a phenomenon in a natural social context by promoting a deep communication interaction process between research and the phenomenon under study. Natural here means that qualitative research is carried out in a natural environment without any intervention or treatment given by the researcher. It is not justified to manipulate or change the research setting (Moleong, 2005). In this study, the researchers took the location in Sabaru Village, Sebangau District, Palangka Raya City in the "Pahari Rattan Craft Group". Researchers chose this location based on the consideration of the problem taken in the title of the study and currently the community in Sabaru Village, Sebangau District, is doing the empowerment of rattan weaving handicrafts.

\section{Results and Discussion}

Community empowerment is very important in responding to the challenges of very high economic growth and increasing global competition, and an absolutely mandatory thing for every element of society to do without exception. For this reason, the wider community is expected to be able to keep up with the times with the empowerment of society which aims to produce independent individuals in society, create an environment that has a good work ethic so as to create healthy and mutually beneficial working conditions, create a society that has high awareness of the potential of themselves and the surrounding environment well, train and enable people to plan and be responsible for their actions in meeting their daily needs, increase the ability to think and negotiate or find solutions to problems that may be encountered in their environment, reduce poverty by means of increasing the potential and basic capabilities of the community.

According to Parsons (1994), empowerment emphasizes that people acquire sufficient skills, knowledge and power to influence their lives and the lives of others who concern them. The empowerment that has been carried out by Ramitje so far has indeed been felt by his students who joined the Pahari Rattan Craftsmen Group, where Ramitje as the group leader must have an expertise in doing a job he is engaged in, such as weaving rattan which is done every day, besides Ramitje doing labor Every day Ramitje can also be invited to provide training outside the region for several days to provide training on the problem of rattan weaving and what handicrafts are produced in weaving rattan.

Empowerment is a process to make people more empowered or more capable to solve their own problems, by providing trust and authority so as to foster a sense of responsibility. Empowerment can be started by encouraging people to want to play a more active role in their work, to involve them in making decisions or responsibilities to complete the work.

In the research I conducted, where a group leader must have several indicators that cover all elements in a job he does. According to Spencer and Spencer (1993), in individuals there are five types of competencies, namely:

1. Motive, competencies related to the consistent thinking of individuals and encouraging them to take action (behave).

2. Inborn traits, competencies related to independent character or character that make individuals behave in certain ways. These innate traits include: self-confidence, endurance, and others.

3. Self concept, competencies related to the attitudes and values of the individual. 
4. Knowledge, competencies related to information or knowledge possessed by individuals in certain fields of work.

5. Skills, competencies related to the individual's physical or mental work

The social value for the people of Sabaru, Sebangau District, where a group of Pahari Rattan Craftsmen is very helpful for the surrounding community who are members of the Pahari Rattan Craftsmen Group in Sabaru Village, Sebangau District to develop creativity in utilizing natural products such as rattan. In this day and age, it is certainly not easy to find a group that can survive by weaving only rattan and produce goods that can be bought and sold, worthy of respect and pride because this Pahari Rattan Craftsman Group can still survive today.

Culture that should be preserved is like weaving rattan. Because, in this day and age, many of our cultures have been lost and forgotten. Because, the times are increasingly rapid and many cultures are being left behind. However, a group of Pahari Rattan Craftsmen has survived and is widely recognized by the public. Culture is the work of humans which is unconsciously written in someone's mind and can produce something useful. One of the local wisdoms that needs to be preserved is woven rattan. This tradition has been carried out by the Dayak people of Central Kalimantan (Central Kalimantan) from generation to generation from the time of their previous ancestors. If the younger generation of Central Kalimantan is not trained in weaving rattan, it is feared that this culture will be eroded by the times. So, we should be proud that the Pahari Rattan Craftsmen Group can still survive and are still developing rattan woven crafts.

In Palangkaraya City, the capital of Central Kalimantan Province, there is a Pahari Rattan Craftsmen Group in the Sabaru Village, Sebangau District. Has a typical rattan woven handicraft. Weaving rattan for craftsmen in the home industry is like weaving life. The raw material for rattan, which is obtained from a number of districts in Central Kalimantan, changes hands before becoming various forms of handicrafts, such as bags, mats, hats, tissue boxes, and sandals. Of course we know that weaving rattan has been around for a long time. And it has a high artistic value because weaving rattan is an art that is owned by someone and is expressed in the form of crafts that can be enjoyed by other people who enjoy the art.

\section{Conclusion}

Based on field observations regarding Community Empowerment in the Development of the Creative Economy of the Pahari Rattan Craftsmen Group in Sabaru Village, Sebangau District, Palangka Raya City. As described above, the authors can draw conclusions. Community economic empowerment carried out by the Pahari Rattan Craftsmen Group in Sabaru Village, Sebangau District, Palangka Raya City in improving the economy of the surrounding community by managing small rattan woven handicrafts is empowerment that refers to the poverty alleviation approach through the production of handicrafts, as for its function is to build and develop the potential for welfare of society from an economic or social point of view. In addition, it also reduces unemployment and absorbs local workers who are part of the Pahari Rattan Craftsmen Group. Empowerment that is directed to form a community structure that reflects the growth of self-help and participation. From the income, processing rattan woven handicrafts can afford education and meet the needs of life. There are not many places where craft groups that we often meet today are proud of us because there are still handicraft groups that can still survive the pace of modernization and current times. Only rattan as raw material, handicraft items produced by the craftsmen group are still in demand by the community. 


\section{References}

Adiwijaya, S., et al. (2018). Empowerment Pattern for Thalasemi Patients in Dr. Soetomo Hospital Surabaya (Study of the Association of Parents with Thalassemia Indonesia, Surabaya). Budapest International Research and Critics Institute-Journal (BIRCIJournal). P. 289-298.

A. M. W. Pranarka Vinhandika Moeljarto. "Pemberdayaan (Empowerment)", dalam onny S. Prijono dan A.M.W Pranarka (eds), 1996. Pemberdayaan : konsep, Kebijakan dan Impelemtasi, CSIS, Jakarta

Abin Syamsuddin Makmun. 2003. Psikologi Pendidikan. Bandung : PT Rosda Karya Remaja

Angsari, Pang S., 2001. Peran Agen Pembaharuan/Penyuluhan dalam Usaha Memberdayakan (empowerment) Sumber Daya Manusia Pengelolaan Agribisnis; Orasi Ilmiah Guru Besar Tetap Ilmu Sosial Ekonomi IPB Bogor, 15 September 2016.

Anwas Oos M., 2014. Pemberdayaan Masyarakat di Era Global. Bandung: ALFABETA.

B. Uno, Hamzah. 2008. Teori Motivasi dan Pengukurannya, Jakarta : Bumi Aksara

Budi Setiawan. Strategi Pengembangan Usaha Kerajinan Bambu (Studi Pada Pejeleran sukahati kecamatan cibinong kabupaten bogor. Jurnal Manajemen dan Organisasi Vol I, No. 2, Agustus 2010. Prodi Manajemen STIE Cibinong, Bogor

Dwi Pratiwi Kurniawati, Bambang Supriyono, Imam Hanafi. Pemberdayaan Masyarakat Di Bidang Usaha Ekonomi (Studi Pada Badan Pemberdayaan Masyarakat Kota Mojokerto). Jurnal Administrasi Publik (JAP), Vol. I, No. 4, Hal. 914

Gerianto, 2016. Proposal Skripsi "Pemberdayaan Masyarakat Petani Dalam Meningkatkan Hasil Panen Melalui Program Gabungan Kelompok Tani (GAPOKAT) Studi Kasus di Desa Netampin Kecamatan Dusun Tengah Kabupaten Barito Timur".

Mawardi et al. (2019). Agenda Empowerment of People in Tarmizi Taher Point of View. Budapest International Research and Critics Institute-Journal (BIRCI-Journal). P. 443-450.

Moleong, 2005. Metodologi Kualitatif Edisi Revisi. Bandung: PT Remaja Rosdakarya

Oos M. Anwas, 2014. Pemberdayaan Masyarakat di Era Global. Bandung:Pustaka Pelajar.

Petir Papilo. Strategi Pemberdayaan Masyarakat Pengrajin Rotan Srudi Kasus Di Kota Pekan Baru. Jurnal Kewirausahaan, Vol 13, No.1, Januari- Juni 2014 Jurnal Kewirausahaan. Jurusan Teknik Industri - Fakultas Sains dan Teknologi UIN Sultan Syarif Kasim Riau.

Rachman, Maman, 1993. Strategi dan Langkah-langkah Penelitian. Semarang: IKIP Semarang Press. Hal. 131

Ramintje J. Asan, 1960. Kumpulan - Kumpulan Motif Dare Anyaman Khas Kalimantan Tengah: Palangka Raya.

Satori Djam'an, dan Komariah Aan, 2014. Metodologi Penelitian Kualitatif. Bandung: Pustaka Pelajar.

Soebiato Poerwoko dan Totok Mardikanto, 2013. Pemberdayaan Masyarakat Dalam Perspektif Kebijakan Publik. Bandung: Alfabeta.

Suharto Edi, 2005. Analisis Kebijakan Publik: Panduan Praktis Mengkaji Masalah dan Kebijakan Sosial. Alfabeta : Bandung.

Sunyoto Usman, 1998. Pembangunan dan Pemberdayaan Masyarakat. Yogyakarta:Pustaka Pelajar. 